\title{
ANALISIS SEKTOR UNGGULAN DALAM MENINGKATKAN PEREKONOMIAN DAN PEMBANGUNAN WILAYAH KABUPATEN KUANTAN SINGINGI
}

\author{
A. Faroby Falatehan ${ }^{1}$, Dylla Novrilasari² \\ 1Staff Pengajar Departemen Ekonomi Sumberdaya dan Lingkungan FEM IPB. \\ Jl. Kamper Wing 5 Level 5 Kampus Kampus IPB Darmaga Bogor 16680 Tlp (0251) 8621834. \\ E-mail: robie_far@yahoo.com \\ ${ }_{2}$ Alumni, Jurusan Sosial Ekonomi Pertanian Faperta IPB.
}

\begin{abstract}
Kuantan Singingi is one of the regencies in Riau Province. Formerly, It was a sub district of Indragiri Hulu regency. Kuantan Singingi regency doesn't have income from oil and gas sector, however it has great potential natural resources. One of the development policies to advance Kuantan Singingi is to give attention for developing leading sectors which is hoped can be rising up or be locomotif of economic regional. The result of research showed that leading sectors in Kuantan Singingi regency are agriculture, mining and quarrying. The results of skalogram analysis found that Kuantan Tengah district take the firt level on development facilities availability and promoting leading sectors. The lowerest level went to Hulu Kuantan district.

Local Government of Kuantan Singingi regency is hoped to be able to support its society economic activities by making priority on agriculture sector, mining and quarrying sector. This priority is important, because LQ analysis found that both sectors are the basis of economy sectors which can increase both the economy and regional development as well as can support non basis of the economy development sectors.
\end{abstract}

Kata Kunci: leading sectors, the economy, development regional

\section{PENDAHULUAN}

Sejalan dengan pelaksanaan otonomi daerah, pemerintah daerah mempunyai kewenangan yang lebih luas dalam menentukan kebijakan dan program pembangunan yang terbaik bagi peningkatan kesejahteraan masyarakat dan kemajuan daerah masing-masing. Latar belakang demografi, geografis, ketersediaan infrastruktur dan budaya yang tidak sama, serta kapasitas sumber daya yang berbeda, memiliki konsekuensi adanya keberagaman kinerja daerah dalam pelaksanaan dan pencapaian tujuan pembangunan. Perbedaan kinerja selanjutnya akan menyebabkan ketimpangan pembangunan antar wilayah,

A. Faroby Falatehan, Dylla Novrilasari meningkatnya tuntutan daerah, dan kemungkinan disintegrasi bangsa.

Kabupaten Kuantan Singingi (Kuansing) merupakan salah satu kabupaten pemekaran di Provinsi Riau memiliki luas wilayah 7.656,03 $\mathrm{Km}^{2}$. Pada awalnya merupakan salah satu kecamatan di dalam pemerintahan Kabupaten Indragiri Hulu. Berdasarkan Undang-Undang Nomor 53 Tahun 1999 Kabupaten Indragiri Hulu dimekarkan menjadi dua kabupaten yaitu Kabupaten Indragiri Hulu dan Kabupaten Kuantan Singingi. Saat ini Kabupaten Kuantan Singingi telah menjadi kabupaten definitif yang terdiri atas 12 kecamatan dan 209 desa/kelurahan.

Pemerintah Daerah Kabupaten Kuantan Singingi perlu melakukan prioritas kebijakan agar pembangunan daerah dapat

Analisis Sektor Unggulan dalam Meningkatkan Perekonomian Pembangunan Wilayah Kabupaten Kuantan Singingi 
berjalan sesuai rencana, baik kebijakan anggaran maupun pengeluaran daerah. Penentuan prioritas kebijakan tersebut dapat diwujudkan salah satunya dengan menentukan sektor prioritas atau unggulan dan melihat pertumbuhan dan perkembangannya. Pertumbuhan sektor ekonomi kabupaten dapat diklasifikasikan berdasarkan laju pertumbuhan dan kontribusi PDRB dari masing-masing sektor. Pertumbuhan sektor perekonomian yang ada di Kabupaten Kuantan Singingi sangat berbeda pada masing-masing sektor, untuk itu perlu dilihat perkembangan sektor ekonomi berdasarkan laju pertumbuhan dan kontribusi PDRB setiap sektor tersebut. Hal ini juga diperlukan untuk pengalokasian dana sektor ekonomi dan untuk mengetahui klasifikasi/pola pertumbuhan dari sektorsektor ekonomi yang ada sebagai pertimbangan untuk menentukan sektor unggulan yang dapat diprioritaskan di Kabupaten Kuantan Singingi. Pertanyaannya adalah bagaimana pola pertumbuhan sektor-sektor ekonomi Kabupaten Kuantan Singingi berdasarkan laju pertumbuhan dan kontribusi PDRB sektor perekonomian?

Sumberdaya alam yang ada di tiap daerah yang berbeda-beda pasti memiliki peran untuk masyarakat sekitarnya asalkan masyarakat mau menggali potensi yang ada didaerahnya dan memanfaatkan dengan sebaik-baiknya tanpa merusak lingkungan sekitar. Kabupaten Kuantan Singingi yang tidak memiliki pendapatan dari migas harus mampu memacu laju pertumbuhan ekonomi, agar tidak tertinggal dengan kabupaten lainnya. Pertanyaannya adalah sektor apa yang menjadi unggulan untuk meningkatkan perekonomian wilayah di Kabupaten Kuantan Singingi serta bagaimana surplus pendapatan dan dampak pengganda pendapatan dari sektor unggulan?

Untuk mencapai tujuan yang telah ditetapkan, Kabupaten Kuantan Singingi yang terdiri dari 12 kecamatan dan 209 desa/kelurahan yang mempunyai potensi dan pola pertumbuhan yang berbeda-beda. Kecamatan yang dekat dengan ibukota kabupaten akan lebih maju daripada kecamatan yang terletak jauh dari ibukota kabupaten. Pembangunan wilayah tidak hanya dilihat dari segi ekonomi saja, namun dapat dilihat dari perkembangan infrastruktur di wilayah tersebut. Pembangunan wilayah dari segi infrastruktur yang ada di Kabupaten Kuantan Singingi harus dapat mendukung sektor unggulan yang ada diwilayah tersebut. Oleh sebab itu, perlu dianalisis infrastruktur sarana dan prasarana yang mendukung perekonomian di Kabupaten Kuantan Singingi. Pertanyaannya adalah bagaimana perkembangan pembangunan wilayah dari segi infrastruktur (sarana dan prasarana) yang mendukung perekonomian dan sektor unggulan di Kabupaten Kuantan Singingi?

Tabel 1. Produk Domestik Regional Bruto Kabupaten Kuantan Singingi Atas Dasar Harga Konstan Menurut Lapangan Usaha Tahun 2002-2006 (Juta Rp)

\begin{tabular}{|l|r|r|r|}
\hline \multicolumn{1}{|c|}{ Lapangan Usaha } & \multicolumn{1}{c|}{$\mathbf{2 0 0 4}$} & \multicolumn{1}{c|}{$\mathbf{2 0 0 5}$} & \multicolumn{1}{c|}{$\mathbf{2 0 0 6}$} \\
\hline Pertanian & $1.165 .081,2$ & $1.223 .751,4$ & $1.287 .849,9$ \\
\hline Pertambangan dan Penggalian & $95.680,7$ & $148.242,5$ & $221.326,1$ \\
\hline Industri Pengolahan & $158.210,2$ & $172.538,8$ & $186.332,6$ \\
\hline Listrik, dan air minum & $3.809,5$ & $3.942,4$ & $4.118,4$ \\
\hline Bangunan & $114.986,5$ & $121.088,8$ & $129.509,7$ \\
\hline Perdagangan, Hotel dan Restoran & $151.423,3$ & $163.757,4$ & $177.510,1$ \\
\hline Pengangkutan dan Komunikasi & $44.897,4$ & $49.050,4$ & 53.477 \\
\hline Keuangan, persewaan dan Jasa Perusahaan & $23.977,5$ & $25.712,9$ & 27.354 \\
\hline Jasa-jasa & 189.366 & $200.716,4$ & $217.525,6$ \\
\hline Produk Domestik Regional Bruto (PDRB) & $1.947 .432,7$ & 2.108 .721 & $2.305 .003,8$ \\
\hline
\end{tabular}

Sumber: BPS, Provinsi Riau, Kuantan Singingi dalam Angka 2006 


\section{METODOLOGI}

\section{Lokasi dan Waktu Penelitian}

Penelitian dilakukan di Kabupaten Kuansing, Provinsi Riau. Penelitian ini dilaksanakan pada bulan Maret sampai dengan April 2008. Pemilihan lokasi penelitian di Kabupaten Kuantan Singingi dipilih secara purposive, dengan pertimbangan bahwa Kabupaten Kuantan Singingi merupakan kabupaten pemekaran yang mempunyai potensi sumberdaya alam yang dapat dikelola untuk meningkatkan perekonomian dan pembangunan wilayah.

\section{Jenis dan Sumber Data}

Jenis data yang digunakan dalam penelitian ini adalah data sekunder yang diperoleh dari Badan Pusat Statistik (BPS) Kabupaten Kuantan Singingi, Badan Perencanaan Pembangunan Daerah (BAPPEDA) Kabupaten Kuantan Singingi, publikasi beberapa penelitian terdahulu, jurnal, artikel, dan internet. Keseluruhan data yang diperlukan untuk analisis pertumbuhan sektor ekonomi wilayah dan sektor unggulan Kabupaten Kuantan Singingi adalah: (1) PDRB Kabupaten Kuantan Singingi; (2) laju pertumbuhan dan kontribusi PDRB Provinsi Riau dan Kabupaten Kuantan Singingi; (3) Data potensi ekonomi Kabupaten Kuantan Singingi, serta berbagai macam data sekunder lainnya.

\section{Metode Analisis Data}

Alat analisis yang digunakan dalam studi penelitian ini secara umum terdiri atas tiga metode, yaitu: analisis pola pertumbuhan sektor ekonomi (Klassen Typologi), analisis Location Quotient, dan analisis skalogram. Pengolahan data dari ketiga metode/alat analisis yang digunakan dalam penelitian ini diolah dengan menggunakan program Microsoft Excel.

\section{a) Analisis Pola Pertumbuhan Ekonomi Sektoral}

Pola pertumbuhan sektor ekonomi wilayah dapat di tentukan dengan analisis Klassen Typologi dengan pendekatan sektoral yang diamati dengan menggabungkan secara sistematis terhadap laju pertumbuhan PDRB dan kontribusi PDRB per sektor, dan setelah itu diklasifikasikan kedalam kelompok/karakteristik menurut Klassen Typologi. Dengan analisis Klassen Typologi dapat diketahui empat klasifikasi pertumbuhan sektor ekonomi, yaitu sektor yang maju dan tumbuh cepat, sektor maju tapi tertekan, sektor potensial atau masih dapat berkembang dengan pesat (sedang tumbuh), dan sektor yang relatif tertinggal.

Klasifikasi Klassen Typologi Pendekatan Sektoral:

\begin{tabular}{|l|l|l|}
\hline & \multicolumn{1}{|c|}{$\boldsymbol{s i}>\boldsymbol{s}$} & \multicolumn{1}{c|}{$\boldsymbol{s i}<\boldsymbol{s}$} \\
\hline $\boldsymbol{g i}>\boldsymbol{g}$ & $\begin{array}{l}\text { sektor maju } \\
\text { dan tumbuh } \\
\text { cepat }\end{array}$ & $\begin{array}{l}\text { sektor } \\
\text { berkembang } \\
\text { cepat } \\
\text { (potensial) }\end{array}$ \\
\hline $\boldsymbol{g i}<\boldsymbol{g}$ & $\begin{array}{l}\text { sektor maju } \\
\text { tetapi tertekan }\end{array}$ & $\begin{array}{l}\text { sektor relatif } \\
\text { tertinggal }\end{array}$ \\
\hline
\end{tabular}

Keterangan:

gi : Laju pertumbuhan PDRB sektoral kabupaten i si : Kontribusi PDRB sektoral kabupaten i

g : Laju pertumbuhan PDRB sektoral Provinsi Riau

S : Kontribusi PDRB sektoral Provinsi Riau

\section{b) Analisis Location Quotient}

Location Quotient (LQ) merupakan perbandingan besarnya peranan suatu sektor di suatu daerah terhadap besarnya peranan sektor tersebut secara nasional. Teknik LQ mengasumsikan: (1) adanya sedikit variasi dalam pola pengeluaran secara geografis; (2) produktivitas tenaga kerja adalah homogen (sama); (3) setiap industri menghasilkan barang yang sejenis didalam sektor yang bersangkutan.

Kriteria LQ>1 menunjukkan peranan sektor tersebut di suatu daerah menonjol
Analisis Sektor Unggulan dalam Wilayah Kabupaten Kuantan Singingi 
dan merupakan sektor surplus serta kemungkinan dapat mengekspor ke daerah lain karena produk tersebut lebih efisien/lebih murah sehingga mempunyai keunggulan komparatif disebut sektor basis.

Analisis LQ (Location Quotient) merupakan metode analisis yang umum digunakan dalam ekonomi geografi. Analisis ini digunakan untuk menunjukkan lokasi pemusatan/basis aktivitas dan mengetahui kapasitas ekspor perekonomian wilayah serta tingkat kecukupan barang/jasa dari produksi lokal suatu wilayah. Nilai LQ merupakan indeks untuk membandingkan pangsa sub wilayah dalam aktivitas tertentu dengan pangsa total aktivitas tersebut secara total. LQ didefinisikan sebagai rasio persentase dari total aktivitas pada sub wilayah ke i terhadap persentase aktivitas total terhadap wilayah yang diamati.

$$
L Q=\frac{S_{i} / N_{i}}{S / N}
$$

Dimana:

LQ : Besarnya kuosien lokasi suatu sektor Ekonomi

$\mathrm{S} \quad$ : PDRB sektor $i$ di Kabupaten Kuantan Singingi

$\mathrm{N}_{\mathrm{i}} \quad$ : Total PDRB di Provinsi Riau $j$

$\mathrm{N}$ : Total PDRB di Kabupaten Kuantan Singingi

\section{b) Pengganda Basis (Multiplier Effect)}

Pengganda basis merupakan suatu metode untuk melihat besarnya pengaruh kegiatan ekonomi basis terhadap peningkatan total pendapatan di suatu wilayah. Nilainya merupakan pembagian jumlah pendapatan total wilayah dengan jumlah pendapatan sektor basis.

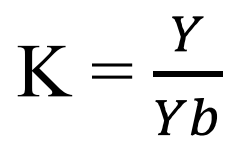

Dimana:

$\mathrm{K}$ : Koeffisien pengganda basis

$\mathrm{Y}_{\mathrm{b}}$ : Pendapatan sektor basis ekonomi di kabupaten Kuantan Singingi

Y : Pendapatan total pendapatan di Kabupaten Kuantan Singingi

\section{c) Analisis Skalogram}

Analisis skalogram adalah analisis yang digunakan untuk mengidentifikasi penyebaran fasilitas sosial dan ekonomi serta hirarki pusat pengembangan dan prasarana pembangunan. Metode ini memberikan hirarki atau peringkat yang lebih tinggi kepada pusat pengembangan yang memiliki jumlah jenis dan jumlah unit prasarana pembangunan yang paling banyak.

Metode ini lebih menekankan kriteria kuantitatif dari pada kriteria kualitatif yang menyangkut derajat fungsi fasilitas pelayanan pembangunan. Metode ini tidak mempertimbangkan aspek distribusi penduduk dan luas jangkauan pelayanan fasilitas pembangunan secara spasial, tetapi dapat memberikan informasi tentang hirarki pusat-pusat pengembangan yang disebabkan oleh penyebaran fasilitas pelayanan pembangunan dalam tata ruang dan hirarki fasilitas pelayanan pembangunan yang terdapat dalam wilayah tersebut.

\section{HASIL DAN PEMBAHASAN}

\section{Identifikasi Pola Pertumbuhan Ekonomi Sektoral Kabupaten Kuantan Singingi}

Berdasarkan Klassen Typologi, pola pertumbuhan sektor ekonomi yang dapat dikategorikan sebagai sektor maju dan tumbuh cepat adalah sektor pertambangan dan penggalian. Sektor inilah yang sebaiknya mendapat perhatian yang lebih dari Pemerintah Daerah Kabupaten Kuantan Singingi untuk dikembangkan. Sektor pertambangan dan penggalian mempunyai kinerja laju pertumbuhan dan kontribusi ekonomi yang lebih besar daripada Provinsi Riau yaitu 52,42 persen rata-rata laju 
Tabel 2. Laju Pertumbuhan PDRB dan Kontribusi PDRB Kabupaten Kuantan Singingi

\begin{tabular}{|l|c|c|c|c|}
\hline \multirow{2}{*}{ Lapangan Usaha } & \multicolumn{2}{c|}{$\begin{array}{c}\text { Laju Pertumbuhan PDRB } \\
\text { rata-rata (persen) }\end{array}$} & \multicolumn{2}{c|}{$\begin{array}{c}\text { Kontribusi PDRB } \\
\text { rata-rata (persen) }\end{array}$} \\
\cline { 2 - 5 } & Riau & Kuantan Singingi & Riau & Kuantan Singingi \\
\hline Pertanian & 6,87 & 5,14 & 38,22 & $\mathbf{6 0 , 7 6}$ \\
\hline Pertambangan dan Penggalian & 27,92 & $\mathbf{5 2 , 4 2}$ & 1,08 & $\mathbf{7 , 0 9}$ \\
\hline Industri Pengolahan & 9,09 & 8,52 & 31,35 & 16,12 \\
\hline Listrik \& Air Minum & 7,53 & 3,97 & 0,37 & 0,15 \\
\hline Bangunan & 7,71 & 6,13 & 4,44 & 3,52 \\
\hline Perdagangan & 10,72 & 8,29 & 11,66 & 5,15 \\
\hline Angkutan \& Komunikasi & 10,04 & 9,13 & 3,39 & 1,17 \\
\hline Keuangan & 16,92 & 6,81 & 3,28 & 0,96 \\
\hline Jasa-jasa & 8,93 & 7,18 & 6,2 & 5,05 \\
\hline
\end{tabular}

Sumber: BPS (diolah)

pertumbuhan dan 7,09 persen untuk kontribusi sektor pertambangan dan penggalian terhadap PDRB Kabupaten Kuantan Singingi. Klasifikasi pola pertumbuhan sektor ekonomi Kabupaten Kuantan Singingi menurut Klassen Typologi dapat dilihat pada Tabel 3.

Sektor pertambangan dan penggalian mempunyai peranan dalam penciptaan nilai tambah pada perekonomian Kabupaten Kuantan Singingi yang dapat dilihat dari peningkatan distribusi PDRB sektor pertambangan dan penggalian dari tahun 2005 sebesar 4,96 persen meningkat tajam menjadi 9,22 persen pada tahun 2006. Ratarata dari kontribusi sektor pertambangan dan penggalian di Kabupaten Kuantan Singingi ini lebih besar daripada kontribusi sektor pertambangan dan penggalian di Provinsi Riau, karena sumberdaya alam
Kabupaten Kuantan Singingi sangat berpotensi di subsektor pertambangan dan penggalian tanpa migas, sedangkan delapan kabupaten/kota di Provinsi Riau berpotensi di subsektor minyak bumi dan gas alam.

Selanjutnya adalah sektor pertanian, yang termasuk kuadran II yaitu sektor maju tetapi tertekan. Sektor ini mempunyai kinerja kontribusi ekonomi yang lebih besar daripada Provinsi Riau yaitu 60,76 persen rata-rata kontribusi PDRB Kabupaten Kuantan Singingi dan 38,22 persen untuk kontribusi sektor pertanian terhadap PDRB Provinsi Riau. Sektor pertanian mempunyai kinerja laju pertumbuhan PDRB yang lebih kecil dibandingkan laju pertumbuhan PDRB sektor pertanian di Provinsi Riau, yaitu sebesar 5,14 persen untuk Kabupaten Kuantan Singingi dan 6,87 persen untuk Provinsi Riau.

Tabel 3. Klasifikasi Pola Pertumbuhan Sektor Ekonomi Kabupaten Kuantan Singingi Menurut Klassen Typologi

\begin{tabular}{|c|c|c|}
\hline \multirow{2}{*}{ Laju PDRB } & \multicolumn{2}{|c|}{ Kontribusi PDRB } \\
\hline & $s i>s$ & $s i<s$ \\
\hline$g i>g$ & $\begin{array}{l}\text { Sektor maju dan berkembang } \\
\text { cepat: Pertambangan dan } \\
\text { penggalian }\end{array}$ & $\begin{array}{c}\text { Sektor berkembang cepat } \\
-\end{array}$ \\
\hline$g i<g$ & $\begin{array}{c}\text { Sektor maju tetapi tertekan: } \\
\text { Pertanian }\end{array}$ & $\begin{array}{l}\text { Sektor relatif tertinggal: } \\
\text { Industri Pengolahan, } \\
\text { Bangunan, Listrik \& air } \\
\text { minum, Perdagangan, } \\
\text { Angkutan \& Komunikasi, } \\
\text { Keuangan dan Jasa-jasa }\end{array}$ \\
\hline
\end{tabular}

Sumber: BPS (diolah) 
Dilihat dari hasil analisis Klassen Typologi tidak ada satu sektor pun yang berada pada kuadran III yaitu sektor potensial atau masih dapat berkembang dengan pesat. Hal ini karena tidak ada sektor yang mampu menunjukkan laju pertumbuhannya yang melebihi kontribusi dan laju pertumbuhan di Provinsi Riau.

Sektor industri pengolahan, bangunan, pengangkutan dan komunikasi, listrik dan air bersih, keuangan, perdagangan, dan jasajasa berdasarkan analisis Klassen Typologi berada di kuadran IV yaitu sektor yang relatif tertinggal. Sektor-sektor ini kurang berkembang, karena laju pertumbuhan dan kontribusi sektor-sektor ini lebih kecil daripada Provinsi Riau. Kebijakan pembangunan yang terpusat pada sektor ini memiliki efek multiplier rendah dan sektor swasta yang kurang berkembang menjadi penyebab sektor-sektor tersebut tidak berkembang.

\section{Analisis Sektor Unggulan di Kabupaten Kuantan Singingi}

Penentuan sektor unggulan di Kabupaten Kuantan Singingi adalah untuk lebih dapat meningkatkan pendapatan dan kesejahteraan masyarakat Kuantan Singingi. Sektor unggulan atau sektor yang berpotensi dalam perekonomian di Kabupaten Kuantan Singingi dapat diketahui dan dapat dikembangkan, karena mampu melayani pasar di daerah itu sendiri maupun diluar daerah yang bersangkutan yang tentunya akan mendapatkan surplus dari perkembangan sektor unggulan ini.

Hasil perhitungan nilai LQ diseluruh sektor perekonomian berdasarkan indikator pendapatan daerah yaitu PDRB atas dasar harga konstan 2000 terdapat dua sektor yang menjadi basis perekonomian Kabupaten Kuantan Singingi pada tahun 2004-2006 yaitu sektor pertanian dan sektor pertambangan dan penggalian, ini ditunjukkan dari hasil perhitungan nilai LQ sektor tersebut lebih dari satu. Hal ini menunjukkan bahwa sektor-sektor tersebut memiliki kontribusi yang besar dalam perekonomian dan pembangunan wilayah di Kabupaten Kuantan Singingi.

Hasil perhitungan analisis sektor basis perekonomian di Kabupaten Kuantan Singingi periode 2004-2006 dapat dilihat pada Tabel 4.

\section{Efek Pengganda Pendapatan}

Angka pengganda pendapatan dijadikan pertimbangan kriteria penentuan sektor unggulan karena suatu sektor mempunyai angka pengganda pendapatan yang tinggi dan jika sektor tersebut dikembangkan diharapkan dapat meningkatkan daya beli masyarakat, atau dengan kata lain bahwa angka penganda pendapatan terkait erat dengan peningkatan daya beli masyarakat dan meningkatkan pendapatan masyarakat. Nilai koefisien mengalami kecenderungan yang menurun dari tahun 2004-2006.

Tabel 4. Nilai LQ Sektor-Sektor Perekonomian di Kabupaten Kuantan Singingi Berdasarkan Harga Konstan 2000 Periode 2004-2006

\begin{tabular}{|c|l|c|c|c|}
\hline No & Lapangan Usaha & $\mathbf{2 0 0 4}$ & $\mathbf{2 0 0 5}$ & $\mathbf{2 0 0 6}$ \\
\hline 1 & Pertanian & $\mathbf{1 , 4 8}$ & $\mathbf{1 , 4 5}$ & $\mathbf{1 , 4 4}$ \\
\hline 2 & Pertambangan dan Penggalian & $\mathbf{4 , 7 9}$ & $\mathbf{6 , 1 0}$ & $\mathbf{6 , 7 5}$ \\
\hline 3 & Industri Pengolahan & 0,48 & 0,48 & 0,47 \\
\hline 4 & Listrik, dan air minum & 0,40 & 0,38 & 0,37 \\
\hline 5 & Bangunan & 0,88 & 0,87 & 0,85 \\
\hline 6 & Perdagangan, Hotel dan Restoran & 0,47 & 0,48 & 0,45 \\
\hline 7 & Pengangkutan dan Komunikasi & 0,40 & 0,39 & 0,39 \\
\hline 8 & Keuangan, persewaan dan Jasa Perusahaan & 0,58 & 0,53 & 0,48 \\
\hline 9 & Jasa-jasa & 0,97 & 0,95 & 0,94 \\
\hline
\end{tabular}

Ket: dicetak tebal adalah sektor basis

Sumber : BPS Kuantan Singingi (di olah) 
Jika dilihat dari efek pengganda per sektor, maka sektor pertambangan memberikan sektor pengganda terbesar, walaupun nilainya terus menurun. Pada tahun 2006 nilai pengganda basis sektor ini adalah 10,41 artinya jika pendapatan sektor basis sebesar Rp 100.000 maka total pendapatan sebesar Rp 1.041 .000 dan Rp 941.000 sektor non basis. Sektor pertanian memiliki efek pengganda pendapatan yang cenderung meningkat selama tahun 20042006. Pada tahun 2006 nilai pengganda basis sebesar 1,78 yang artinya jika terjadi peningkatan pendapatan sektor basis sebesar Rp 100.000 maka total pendapatan sebesar $\mathrm{Rp} 1.780 .000$ sektor basis dan Rp 1.680 .000 sektor non basis.

\section{Analisis Skalogram}

\section{a) Perkembangan Infrastruktur dalam Pembangunan Wilayah}

Berdasarkan hasil skalogram, hanya Kecamatan Kuantan Tengah yang memiliki fasilitas yang lengkap. Kecamatan Kuantan Tengah memiliki 37 jenis fasilitas. Kecamatan Kuantan Tengah merupakan kecamatan yang paling banyak jumlah penduduknya, sehingga kelengkapan fasilitas sangat diperlukan. Selain itu juga Kecamatan Kuantan Tengah merupakan ibukota Kabupaten Kuantan Singingi sehingga memungkinkan kecamatan ini memiliki fasilitas yang tidak dimiliki kecamatan lainnya. Disusul oleh Kecamatan Benai dengan 29 fasilitas. Hal ini disebabkan karena Kecamatan Benai merupakan Kecamatan yang dekat dengan ibukota Kabupaten Kuantan Singingi yaitu Teluk Kuantan Kecamatan Kuantan Tengah dan jumlah penduduknya berada pada peringkat dua paling banyak.

Kecamatan Hulu Kuantan merupakan kecamatan yang mempunyai jumlah dan jenis fasilitas yang paling sedikit yaitu 18 fasilitas, ini disebabkan karena Kecamatan Hulu Kuantan merupakan kecamatan yang paling sedikit penduduknya. Selain itu, Kecamatan Hulu Kuantan merupakan kecamatan pemekaran dari Kecamatan Kuantan Mudik, kecamatan ini masih tergolong baru dan masyarakatnya masih relatif kurang maju dibandingkan masyarakat di kecamatan lain di Kabupaten Kuantan Singingi.

Hasil analisis skalogram Kecamatan Kuantan Tengah memegang peringkat pertama dalam ketersediaan fasilitas pembangunan yaitu 1.432. ini disebabkan karena Kecamatan Kuantan Tengah merupakan ibukota dari Kabupaten Kuantan Singingi sehingga penyebaran fasilitas pembangunan dilakukan di kecamatan tersebut. Hirarki terendah dipegang oleh Kecamatan Hulu Kuantan dengan jumlah fasilitas 78, selain karena jumlah penduduknya yang sedikit, Kecamatan Hulu Kuantan merupakan daerah baru dari hasil pemekaran Kecamatan Kuantan Mudik.

Umumnya jumlah penduduk sebagai indikator dalam alokasi fasilitas pembangunan. Namun, dari hasil skalogram selain jumlah penduduk, jumlah desa menentukan alokasi fasilitas pembangunan. Hasil analisis ini diperlukan untuk mendukung hasil analisis sektor basis, sehingga sektor basis yang akan dikembangkan pada suatu wilayah dapat berkembang baik dengan dukungan fasilitas-fasilitas yang dibutuhkan. Perbedaan jumlah dan jumlah unit fasilitas sosial ekonomi yang dimiliki oleh tiap kecamatan di Kabupaten Kuantan Singingi diharapkan memberikan peranan yang sesuai dalam menunjang pembangunan wilayah dan perekonomian masyarakat Kabupaten Kuantan Singingi.

\section{b) Perkembangan Infrastruktur Pendukung Sektor Unggulan}

Pusat pertumbuhan dan pelayanan dalam suatu wilayah akan memberikan keuntungan pada wilayah tersebut tersebut. Keuntungan berupa adanya konsentrasi yang lebih dalam memproduksi suatu komoditi hasil dari sektor perekonomian tertentu, terciptanya kemudahan-kemudahan hubungan antara daerah dalam pendistribusian komoditi, misalnya aksesibilitas transportasi relatif murah dan mudah dan pelayanan masyarakat. Sektor unggulan yang akan diprioritaskan untuk 
peningkatan pendapatan masyarakat dan pembangunan wilayah akan didukung oleh ketersediaan sarana dan prasarana yang cukup untuk mendukung aktivitas perekonomian dan yang mendukung perkembangan sektor unggulan tersebut.

Dalam analisis skalogram dapat di asumsikan beberapa sarana dan prasarana yang mendukung perkembangan sektor unggulan di Kabupaten Kuantan Singingi, yaitu; pasar, koperasi, kelompok tani, penyuluh praktek lapang (PPL), perusahaan pertanian, perusahaan pertambangan eksploitasi maupun eksplorasi, bank, wartel, warnet, dan terminal bus.

Hasil analisis skalogram Kecamatan Kuantan Tengah memegang peringkat pertama dalam ketersediaan fasilitas pendukung sektor unggulan yaitu 164. Ini disebabkan karena Kecamatan Kuantan Tengah merupakan ibukota dari Kabupaten Kuantan Singingi sehingga penyebaran fasilitas pembangunan dilakukan di kecamatan tersebut. Walaupun di Kecamatan Kuantan Tengah hanya terdapat tiga perusahaan pertanian, tetapi memiliki jumlah koperasi yang paling banyak dibandingkan dengan kecamatan lain nya Hirarki terendah dipegang oleh Kecamatan Hulu Kuantan yaitu dengan jumlah fasilitas 41. Kecamatan Hulu Kuantan mempunyai dua perusahaan di sektor pertanian dan pertambangan, tetapi kecamatan ini masih berada pada peringkat terakhir, hal ini disebabkan karena fasilitas pendukung yang lainnya masih kurang, selain itu jumlah penduduknya yang sedikit dapat mempengaruhi ketersediaan dan penyebaran sarana dan prasarana yang ada di setiap kecamatan.

Perusahaan-perusahaan

yang mendukung sektor pertanian dan sektor pertambangan hampir merata tersebar di Kabupaten Kuantan Singingi dengan potensi sumberdaya alam yang tersedia di masing-masing kecamatan. Perusahaan ini bergerak di bidang perkebunan seperti perusahaan kelapa sawit dan karet serta di bidang pertambangan adalah tambang batu bara, karena barang tambang yang lainnya seperti emas dan pasir masih dikelola oleh masyarakat dan belum ada peran swasta dan pemerintah daerah Kabupaten Kuantan Singingi. Perusahaan perkebunan swasta yang tersebar di Kabupaten Kuantan Singingi paling banyak terdapat di Kecamatan Singingi Hilir yang mempunyai lima lokasi perusahaan perkebunan dan Kecamatan Kuantan Mudik, Pangean, dan Hulu Kuantan mempunyai masing-masing satu lokasi perusahaan perkebunan.

Perkembangan dan pembangunan wilayah dapat dilihat dari peningkatan pendapatan dan perekonomian suatu wilayah, untuk itu diperlukan adanya penyediaan sarana dan prasarana fasilitas ekonomi pada suatu wilayah. Fasilitas ekonomi yang mendukung kegiatan perekonomian penduduk di suatu wilayah meliputi pasar, koperasi, bank. Di samping sebagai fasilitas pelayanan ekonomi penduduk, pasar juga merupakan sumber (potensi) yang perlu dikembangkan guna menunjang perkembangan perekonomian suatu wilayah. Pasar dapat memberi kontribusi terhadap peningkatan pendapatan daerah yang bersumber dari retribusi.

Fasilitas pelayanan ekonomi bank mempunyai peranan yang penting dalam pembangunan Kuantan Singingi, terutama dalam meningkatkan pendapatan daerah yang diperoleh dari bagian laba bank dan penerima jasa deposito. Bank berfungsi untuk sebagai pemberi kredit, pengadaan modal dan tempat penyimpan uang bagi penduduk Kabupaten Kuantan Singingi. Kecamatan Kuantan Tengah merupakan kecamatan yang memiliki jumlah fasilitas pelayanan ekonomi berupa bank terbanyak. Hal ini karena Kecamatan Kuantan Tengah merupakan ibukota kabupaten dan sebagai pusat pemerintahan di Kabupaten Kuantan Singingi.

Dinamika penduduk dipengaruhi oleh fasilitas perhubungan dan telekomunikasi pada suatu wilayah. Semakin memadai fasilitas yang tersedia maka akan semakin mudah bagi penduduk tersebut untuk berinteraksi dengan wilayah disekitarnya. Fasilitas perhubungan dan telekomunikasi juga sangat berpengaruh terhadap pemenuhan kebutuhan hidup penduduk 
yang tidak dapat di daerahnya. Fasilitas perhubungan dan telekomunikasi dalam pembangunan wilayah berperan sebagai mobilisator dan dinamisator dalam pelaksanaan pembangunan wilayah.

Saat ini teknologi komunikasi telah mengalami perkembangan sehingga untuk memenuhi kebutuhan penduduk tidak hanya ditentukan oleh jarak tetapi juga faktor waktu yang yang terbuang dan biaya yang harus dikeluarkan disetiap wilayah. Fasilitas penghubung lainnya seperti terminal bus, keberadaan terminal bus ini menjadi sektor perhubungan dan komunikasi sebagai sektor basis antar kecamatan yang ada yang sangat bermanfaat bagi perkembangan Kabupaten Kuantan Singingi kedepannya.

Selain dari sarana dan prasarana yang dijelaskan di atas, untuk mendukung terciptanya sarana dan prasarana sektor unggulan dengan baik diperlukan prasarana jalan yang baik. Prasarana jalan merupakan urat nadi kelancaran lalu lintas di darat. Lancarnya lalu lintas akan menunjang perkembangan perekonomian suatu daerah. Guna menunjang kelancaran perhubungan darat di Kabupaten Kuantan Singingi, pada tahun 2006 tercatat panjang jalan kabupaten $1.941,150 \mathrm{~km}$ dengan kondisi yang baik sepanjang $543,78 \mathrm{~km}$, sedang $1.275,5 \mathrm{~km}$, dan rusak $121,87 \mathrm{~km}$. Jika panjang jalan dirinci menurut jenis permukaan, maka $312,365 \mathrm{~km}$ jalan aspal, $1.328,552 \mathrm{~km}$ jalan kerikil dan 300,233 km jalan tanah.

Prasarana jalan yang berfungsi sebagai penunjang perekonomian Kabupaten Kuantan Singingi, khususnya dalam peningkatan sektor unggulan di setiap kecamatan agar dapat menyebar merata dan dapat mengirim hasil dari sektor unggulan tersebut seperti hasil dari komoditi pertanian dan pertambangan baik di dalam maupun di luar daerah Kabupaten Kuantan Singingi dengan arus transportasi yang lancar.

\section{Implikasi Kebijakan}

\section{a) Kebijakan Pembangunan Sektoral}

Kebijakan pembangunan wilayah dalam meningkatkan perekonomian di Kabupaten Kuantan Singingi diprioritaskan pada dua sektor tersebut, karena kedua sektor ini sangat berperan penting dalam menghasilkan pendapatan. Selain itu, kedua sektor tersebut sebagai sektor basis juga diharapkan mampu meningkatkan pertumbuhan pendapatan wilayah Kabupaten Kuantan Singingi. Beberapa implikasi kebijakan dari setiap sektor adalah sebagai berikut:

1) Implikasi kebijakan dari sektor pertanian diharapkan dapat membantu masyarakat petani dengan adanya penyebaran perusahaan pertanian dan PPL untuk dapat membantu masyarakat petani khususnya dalam pengelolaan lahan pertanian di setiap kecamatan. Peran swasta dalam mengelola hasil pertanian khususnya di bidang perkebunan agar dapat memberi bantuan kepada masyarakat dengan penyerapan tenaga kerja dan pendapatan masyarakat.

2) Sektor pertanian dapat menghasilkan nilai tambah dan partisipasi masyarakat yang terus meningkat dan berkembang dengan dilakukannya usaha pertanian yang berwawasan bisnis/agribisnis dan agrowisata di Kabupaten Kuantan Singingi. Selain itu juga agroindustri sebagai subsistem agribisnis yang mempunyai potensi sebagai pendorong pasar yang lebih luas dan nilai tambah (value added) yang besar.

3) Kebijakan dari subsektor kehutanan diharapkan dapat menjadikan dan mengembangkan perhutanan sosial sebagai penyeimbang ekosistem dan pelestarian lingkungan khususnya di Kabupaten Kuantan Singingi dan Provinsi Riau umumnya. Dengan adanya perhutanan sosial tersebut dapat meminimalisasi penebangan hutan secara liar dan kebakaran hutan diberbagai daerah.

4) Implikasi dari sektor pertambangan yaitu dengan mendorong tumbuh dan kembangnya usaha di bidang pertambangan umum, energi, dan sumberdaya mineral. Perlu adanya pembinaan dan pengawasan di bidang pertambangan dengan tersedianya data 
pertambangan umum secara akurat dan valid, serta perlu adanya kegiatan yang dapat menambah pengetahuan masyarakat atau pemerintah daerah sendiri dengan diadakannya diklat/kursus teknis bidang pertambangan agar potensi sumberdaya alam yang ada tidak disia-sia kan dan hanya diberikan kepada investor yang ada atau perusahaan saja yang mengelola.

5) Dengan adanya implementasi kebijakan dari sektor pertambangan juga diperlukan pengawasan dan penertiban kegiatan rakyat yang berpotensi merusak lingkungan agar terwujudnya pertambangan rakyat secara tertib. Monitoring, evaluasi dan pelaporan dampak kerusakan lingkungan akibat kegiatan pertambangan rakyat harus di data secara valid agar tidak merugikan masyarakat sekitar daerah pertambangan tersebut. Khususnya tambang emas yang ada di Kecamatan Singingi masih dikelola oleh masyarakat setempat dan belum ada peranan dari swasta.

6) Perkembangan dan pertumbuhan sektor unggulan pertanian dan pertambangan perlu didukung oleh sektor lainnnya yang merupakan sektor non basis, sehingga selain dapat memacu perkembangan dan pertumbuhan sektor unggulan tersebut juga dapat memacu perkembangan dan pertumbuhan sektor lainnya yang merupakan sektor non basis sehingga menunjang keberadaan sektor basis, seperti adanya sektor industri pengolahan akan mendukung pengolahan hasil pertanian dan pertambangan, begitu juga dengan sektor non basis lainnya.

\section{b) Kebijakan Menurut Penyebaran Fasilitas Pembangunan dan Pendukung Sektor Unggulan}

Berdasarkan hasil analisis dari metode skalogram, penyebaran sarana dan prasarana pembangunan wilayah dan mendukung perekonomian Kabupaten Kuantan Singingi dapat dikatakan belum mengalami pemerataan. Implikasi kebijakan yang dapat direkomendasikan dalam kebijakan sarana dan prasarana pendukung sektor unggulan adalah sebagai berikut:

1) Dalam penyusunan perencanaan pembangunan di masa yang akan datang sebaiknya berpedoman pada perencanaan pembangunan terpadu antar sektor. Dalam bentuk lain dapat dikatakan bahwa sektor ekonomi yang tergolong basis harus mendapat prioritas utama. Pembangunan dapat berjalan dengan lancar apabila sarana dan prasarana fasilitas pendukung pembangunan lengkap. Pemerintah Kabupaten Kuantan Singingi perlu memperhatikan wilayah yang sarana dan prasarananya kurang lengkap seperti Kecamatan Hulu Kuantan yang memiliki potensi sektor unggulan yang baik, tetapi penyebaran dan ketersediaan sarana dan prasarananya belum memadai.

2) Kebijakan dalam meningkatkan pembangunan dan pemeliharaan sarana dan prasarana publik/masyarakat untuk mendorong pemerataan pembangunan, percepatan dan pertumbuhan ekonomi daerah dilakukan dengan adanya perencanaan tata ruang agar terwujudnya tata ruang kota dan desa sebagai acuan pelaksanaan pembangunan, pemanfaatan tata ruang agar tersedianya sarana dan prasarana wilayah yang memadai dan terkendalinya ruang kota dan desa secara optimal.

3) Pembangunan berkelanjutan juga harus mendapat perhatian serius dalam memgembangkan sekor unggulan. Keberlanjutan usaha-usaha ekonomi sektor unggulan harus diiringi dengan pengelolaan pembangunan keseluruhan secara arif dengan memperhatikan kelestarian lingkungan sehingga dalam pelaksanaannya tetap berpedoman pada paradigma pembangunan berkelanjutan.

4) Adanya otonomi daerah menuntut daerah untuk dapat memperbesar PAD yang akan digunakan sebagai sumber dana pembangunan daerahnya. Sesuai 
dengan prioritas pembangunan di Kabupaten Kuantan Singingi maka pembangunan dilaksanakan lebih mengutamakan pada pembangunan sektor yang potensial untuk dikembangkan di Kabupaten Kuantan Singingi. sektor perekonomian yang dapat dikembangkan dan diprioritaskan menjadi sektor unggulan adalah sektor pertanian dan sektor pertambangan dan penggalian.

5) Implikasi kebijakan dalam penyebaran sarana dan prasarana wilayah di setiap kecamatan Kabupaten Kuantan Singingi yang belum sepenuhnya mengalami pemerataan, diharapkan kepada pemerintah daerah agar dapat memperhatikan dan menindaklanjuti keadaan sarana dan prasarana wilayah kecamatan yang kurang merata untuk mendukung perekonomian Kabupaten Kuantan Singingi, terutama bagi daerah kecamatan yang jauh dari ibukota kabupaten dan daerah kecamatan baru hasil pemekaran. Seperti Kecamatan Hulu Kuantan, Kecamatan Cerenti, Kecamatan Inuman dan kecamatan lain yang belum ada sarana dan prasarana pendukung dari sektor unggulan yang diprioritaskan oleh pemerintah daerah Kabupaten Kuantan Singingi dalam meningkatkan perekonomian dan pembangunan wilayahnya.

6) Implikasi kebijakan fasilitas pendidikan untuk mendukung sektor unggulan dapat dilakukan dengan cara mendirikan dan menambah sekolah kejuruan yang bergerak dalam bidang pertanian dan pertambangan, hal ini diperlukan untuk menciptakan sumberdaya manusia dan pengetahuan masyarakat dini tentang pertanian dan pertambangan tersebut, agar tidak tertinggal dengan daerah lain.

\section{PENUTUP}

\section{Kesimpulan}

1) Hasil dari analisis Klassen Typologi dengan pendekatan sektoral, menunjukkan bahwa sektor pertambangan dan penggalian menduduki kuadran I yaitu sektor maju dan tumbuh cepat. Disusul oleh sektor pertanian pada kuadran II yaitu sektor maju tetapi tertekan. Selain dari dua sektor ini, sektor ekonomi di Kabupaten Kuantan Singingi masih banyak berada pada kuadran IV yaitu sektor yang relatif tertinggal.

2) Hasil perhitungan nilai LQ diseluruh sektor perekonomian berdasarkan indikator pendapatan daerah yaitu PDRB atas dasar harga konstan 2000 terdapat dua sektor yang menjadi basis perekonomian Kabupaten Kuantan Singingi yang dapat diprioritaskan menjadi sektor unggulan pada tahun 2002-2006 yaitu sektor pertanian dan sektor pertambangan dan penggalian. Hal ini menunjukkan bahwa sektorsektor tersebut memiliki kontribusi yang besar dalam perekonomian dan pembangunan wilayah di Kabupaten Kuantan Singingi. Kedua sektor tersebut memiliki nilai surplus pendapatan dan pengganda pendapatan yang positif dan cenderung meningkat.

3) Hasil analisis skalogram Kecamatan Kuantan Tengah memegang peringkat pertama dalam ketersediaan fasilitas pembangunan. Peringkat terendah dipegang oleh Kecamatan Hulu Kuantan. Jika dilihat dari hasil metode skalogram Kecamatan Kuantan Tengah masih berada pada peringkat pertama, dan Kecamatan Hulu Kuantan tetap peringkat terakhir. Perusahaan yang mendukung peranan sektor unggulan tersebar di beberapa kecamatan yang memiliki potensi sumberdaya alam dan lokasi perkebunan yang luas.

\section{Saran}

1) Pemerintah Daerah Kabupaten Kuantan Singingi diharapkan untuk mampu menopang perekonomian masyarakatnya dengan memprioritaskan sektor pertanian serta sektor pertambangan dan penggalian sebagai sektor unggulan, karena 
berdasarkan analisis LQ kedua sektor tersebut merupakan sektor basis perekonomian yang dapat meningkatkan perekonomian dan pembangunan wilayah serta dapat mendukung perkembangan sektor perekonomian non basis.

2) Berdasarkan analisis LQ diharapkan kepada pemerintah daerah juga memperhatikan dan memperbaiki faktor-faktor pendukung yang mempengaruhi perkembangan sektor non basis, sehingga dapat menambah dan menjadikan sektor non basis sebagai sektor basis yang dapat diprioritaskan sebagai sektor unggulan Kabupaten Kuantan Singingi, seperti sektor bangunan, transportasi dan komunikasi dan lainnya. Misalnya dengan peningkatan terhadap penguasaan teknologi pada semua sektor yang ada dan mempermudah persyaratan dalam penanaman investasi, meningkatkan jaringan komunikasi dan infrastruktur yang mendukung.

3) Sebaiknya pembangunan sarana dan prasarana ditingkatkan di wilayah kecamatan yang terletak jauh dari ibukota kecamatan seperti Kecamatan Hulu Kuantan, Kecamatan Cerenti, Kecamatan Inuman dan kecamatan lainnya yang relatif masih tertinggal serta daerah yang banyak memiliki potensi dari sektor unggulan seperti Kecamatan Singingi Hilir.

\section{DAFTAR PUSTAKA}

Anwar, A. 2005. Ketimpangan Pembangunan Wilayah dan Perdesaan. P4Wpress. Bogor.

Budiharsono, Sugeng. 2001. Teknik Analisis Pembangunan Wilayah Pesisir dan Lautan. PT Pradnya Paramita. Jakarta.

Glasson, J. 1977. Pengantar Perencanan Regional (terjemahan Paul Sitohang). LPFEUI, Jakarta.

Hanafiah, T. 1988. Pengembangan Pusat Pertumbuhan dan Pelayanan Kecil dalam Rangka Pengembangan Wilayah Pedesaan. Jurusan Sosial Ekonomi Pertanian Faperta IPB. Bogor.

Jhingan, ML. 1999. Ekonomi Pembangunan dan Perencanaan. Raja Grafindo Persada, Jakarta.

Richardson, H. 2001. Dasar-Dasar Ilmu Ekonomi Regional. Fakultas Ekonomi Universitas Indonesia. Jakarta.

Sukirno, S. 1985. Ekonomi Pembangunan (Proses, Masalah, dan Dasar Kebijaksanaan). LPFE UI.Jakarta.

Usya, N. 2006. Analisis Struktur Ekonomi dan Identifikasi Sektor Unggulan di Kabupaten Subang. Fakultas Ekonomi dan Manajemen. IPB. Bogor. 